\title{
Phenolic Constituents, Antimicrobial, Antioxidant, and Anticancer Activities of Ethyl Acetate and $n$-Butanol Extracts of Senna italica
}

\author{
Omar M. Khalaf ${ }^{1}$, Mosad A. Ghareeb ${ }^{2 *}$, Amal M. Saad ${ }^{2}$, Hassan M. F. Madkour ${ }^{1}$, \\ Ahmed K. El-Ziaty ${ }^{1}$ and Mohamed S. Abdel-Aziz ${ }^{3}$ \\ ${ }^{1}$ Chemistry Department, Faculty of Science, Ain Shams University, El-Khalifa El-Mamoun, 11566 Abbassia, Cairo, Egypt \\ ${ }^{2}$ Medicinal Chemistry Department, Theodor Bilharz Research Institute, Kornaish El-Nile, 12411 Warrak El-Hadar, \\ Imbaba (P.O. 30), Giza, Egypt \\ ${ }^{3}$ Microbial Chemistry Department, Genetic Engineering and Biotechnology Division, National Research Centre, \\ El Behoos Street 33, Dokki-Giza 12622, Egypt
}

Received: 12 November 2017; accepted: 04 December 2017

\begin{abstract}
Different solvent extracts of the aerial parts of Senna italica (Mill.) were investigated for their chemical constituents and biological activities. Moreover, bio-guided fractionation led to isolation and identification of six compounds, namely: physcion (1), emodin (2), 2-methoxy-emodin-6- $O$ - $\beta$-D-glucopyranoside (3), 1-hydroxy-2-acetyl-3-methyl-6hydroxy-8-methoxynaphthalene (tinnevellin) (4), quercetin 3-O- $\alpha$-L-rhamnopyranosyl- $(1 \rightarrow 6)-\beta$-D-glucopyranoside (rutin) (5), and 1,6,8-trihydroxy-3-methoxy-9,10-dioxo-9,10-dihydroanthracene (6). The chemical structures of these compounds were established via $1 \mathrm{D}$ and $2 \mathrm{D}{ }^{1} \mathrm{H}$ - and ${ }^{13} \mathrm{C}$-NMR spectroscopy. Ethyl acetate and $n$-butanol extracts as well as compound $\mathbf{3}$ were evaluated for their anticancer activity against tumor cell lines. The tested extracts showed a moderate to weak activity, while compound $\mathbf{3}$ showed a moderate activity against human liver cancer (Hep G2) and breast cancer (MCF-7) cell lines with $\mathrm{IC}_{50}$ values of 57.5 and $42.3 \mu \mathrm{g} / \mathrm{mL}$, respectively. Both ethyl acetate and $n$-butanol extracts exhibited antimicrobial activities with different strengths, i.e., ethyl acetate exhibited antimicrobial activity against seven test microbes while $n$-butanol extract showed antimicrobial activity against all tested microbes. This is the first report for the isolation of compound $\mathbf{3}$ as a new compound from $S$. italica growing in Egypt.
\end{abstract}

Keywords: Senna italica, antimicrobial, anticancer, ABTS, anthraquinones

\section{Introduction}

Family Fabaceae/Leguminosae, commonly known as the legume, comprises about 730 genera and more than 19,000 species [1]. Senna is an important genus of flowering plants, comprising nearly of 350 species. It is widely distributed in tropical and subtropical zones $[2,3]$. This genus is known to be rich in different secondary metabolites, especially anthraquinones [4]. Physcion, chrysophanol, 10,10'-chrysophanol bianthrone, 1,1,8,8'-tetrahydroxy-6'-methoxy-3,3'-dimethyl-10,10'-bianthracen-9,9'-dione, and 1,1,8,8'-tetrahydroxy-7'-methoxy-3,3'-dimethyl-10,10'-bianthracen$9,9^{\prime}$-dione were isolated from pods of Senna italica growing in Sudan [4]. Moreover, 5-acetonyl-7-hydroxy-2-methylchromone, 5-acetonyl-7-hydroxy-2-hydroxymethyl-chromone, 4-(trans)acetyl-3,6,8-trihydroxy-3-methyldihydronaphthalenone, and 4(cis)-acetyl-3,6,8-trihydroxy-3-methyldihydronaphthalenone were isolated from leaves of $S$. siamea growing in Thailand $[5,6]$. Branco et al. (2011) reported the isolation of 2-acetyl physcion (2-acetyl-1,8-dihydroxy-6-methoxy-3-methyl-9,10 anthraquinone), chrysophanol, and chrysophanol-8-methyl ether from the bark of Senna macranthera growing in Brazil [6]. On the other hand, previous studies indicated that Senna species showed broad spectrum of biological applications such as antibacterial [7], anti-inflammatory [8], antitrypanosomal [9], antiprotozoal [10], antioxidant [11], and antiproliferative [12]. Anthraquinones are known by their vital pharmacological activities including antioxidant [13], antimalarial, antituberculosis [14], and antimicrobial [15]. Also, many authors have studied the anticancer activity of anthraquinones against different tumor cell lines like murine B16-F10 melanoma [16], lung [17], liver (HepG-2), colon (HCT-116), kidney (MCF-7) [18],

* Author for correspondence: m.ghareeb@tbri.gov.eg hepatoma [19], human B-lymphoblastoid, and HL-60 [20]. Therefore, the current study was conducted to isolate and identify anthraquinone compounds from aerial parts of $S$. italica and to evaluate the antimicrobial, anticancer, and antioxidant activities of two solvent extracts as well as a new pure isolate.

\section{Experimental}

General Experimental Procedures. Hydrogen-1 nuclear magnetic resonance $\left({ }^{1} \mathrm{H}-\mathrm{NMR}\right)$ and carbon-13 nuclear magnetic resonance $\left({ }^{13} \mathrm{C}\right.$-NMR) spectra were recorded on Bruker Avance III $400 \mathrm{MHz}$ for ${ }^{1} \mathrm{H}$ and $100 \mathrm{MHz}$ for ${ }^{13} \mathrm{C}$ (Bruker $\mathrm{AG}$, Switzerland) with Broad Band Fluorine Observation (BBFO) Smart Probe and Bruker 400 AEON Nitrogen-Free Magnet. Data were analyzed using Topspin 3.1 Software, NMR unit at the Faculty of Pharmacy, Beni Suef University, Egypt. Chemical shifts are given in $\delta$ values (ppm) using tetramethylsilane (TMS) as the internal standard. Column chromatography (CC) was carried out on Silica gel (70230 mesh) (Merck), Polyamid 6S (Sigma-Aldrich), and Sephadex LH-20 (Uppsala, Sweden).

Plant Materials. The aerial parts of $S$. italica were collected from Alkharga Oasis desert, Alwady Algaded, Egypt during March, 2015. The plant was kindly identified by Prof. Dr. Ibrahim A. Mashaly, professor of Plant Ecology and Flora, Botany Department, Faculty of Science, Mansoura University. Voucher specimens were kept in Medicinal Chemistry Department, Theodor Bilharz Research Institute, Kornaish El-Nile Str., Warrak El-Hadar, Imbaba, Giza, Egypt.

Extraction and Chromatographic Isolation. The air-dried powdered aerial parts of $S$. italica $(1.5 \mathrm{~kg})$ were soaked in a mixture of organic solvents composed of $\mathrm{CH}_{2} \mathrm{Cl}_{2}-\mathrm{MeOH}(1: 1, \mathrm{v} / \mathrm{v})$

This is an open-access article distributed under the terms of the Creative Commons Attribution-NonCommercial 4.0 International License (https://creativecommons.org/licenses/by-nc/4.0/), which permits unrestricted use, distribution, and reproduction in any medium for non-commercial purposes, provided the original author and source are credited, a link to the CC License is provided, and changes - if any - are indicated. 
for $72 \mathrm{~h}$ at room temperature [21], and the solvent was removed via evaporation under vacuum to give a yield of $100 \mathrm{~g}$ of crude extract. The crude extract was dissolved in organic solvents with increasing polarities, i.e., hexane, methylene chloride, ethyl acetate, and $n$-butanol to afford 9.87, 17.42, 23.82, and $35.96 \mathrm{~g}$, respectively. Methylene chloride extract (15 g) was chromatographed on a column packed with $200 \mathrm{~g}$ of silica gel, and the column was eluted with $\mathrm{CH}_{2} \mathrm{Cl}_{2}, \mathrm{CH}_{2} \mathrm{Cl}_{2}-\mathrm{MeOH}$, and $\mathrm{MeOH}$. Based on TLC studies, fractions I and II were monitored and collected using $n$-hexane and ethyl acetate solvent mixture $(11: 9, \mathrm{v} / \mathrm{v})$ and both of them were further purified on preparative thin-layer chromatography (PTLC), two anthraquinones aglycones, namely, physcion (1) and emodin (2) were isolated via PTLC using (n-hexane-benzene-ethyl acetate; 2:0.4:2.4, v/v/v) as elution system. The ethyl acetate extract (20 g) was undergoing chromatographic isolation up on polyamide $6 \mathrm{~S}$ column packed with $250 \mathrm{~g}$ of polyamide as stationary phase. The elution system was started with $\mathrm{H}_{2} \mathrm{O}, \mathrm{H}_{2} \mathrm{O}-\mathrm{MeOH}(1: 1, \mathrm{v} / \mathrm{v}), \mathrm{MeOH}, \mathrm{MeOH}-$ $\mathrm{AcOH}(1: 1, \mathrm{v} / \mathrm{v}), \mathrm{AcOH}, \mathrm{AcOH}-\mathrm{NH}_{3}(1: 1, \mathrm{v} / \mathrm{v})$, and finally with $\mathrm{NH}_{3}$. A major fraction (III) was purified on Sephadex LH-20 sub-column eluted with $\left(\mathrm{CH}_{2} \mathrm{Cl}_{2}-\mathrm{MeOH} ; 9: 1, \mathrm{v} / \mathrm{v}\right)$ followed by PTLC using (EtOAc- $\left.-\mathrm{MeOH}-\mathrm{H}_{2} \mathrm{O} ; 8.6: 1: 0.4, \mathrm{v} / \mathrm{v} / \mathrm{v}\right)$ to give two compounds, namely, 2-methoxy-emodin-6- $O-\beta-\mathrm{D}-$ glucopyranoside (3) and 1-hydroxy-2-acetyl-3-methyl-6-hydroxy8-methoxynaphthalene (tinnevellin) (4). Finally, the $n$-butanol extract $(30 \mathrm{~g})$ was undergoing chromatographic isolation up on polyamide $6 \mathrm{~S}$ column. The elution system was started with $\mathrm{H}_{2} \mathrm{O}$, $\mathrm{H}_{2} \mathrm{O}-\mathrm{MeOH}(1: 1, \mathrm{v} / \mathrm{v}), \mathrm{MeOH}, \mathrm{MeOH}-\mathrm{AcOH}(1: 1, \mathrm{v} / \mathrm{v}), \mathrm{AcOH}$, $\mathrm{AcOH}-\mathrm{NH}_{3}(1: 1, \mathrm{v} / \mathrm{v})$, and finally with $\mathrm{NH}_{3}$. Two obtained major fractions (IV and V); fraction (IV) was purified on Sephadex LH20 eluted with $\left(\mathrm{CH}_{2} \mathrm{Cl}_{2}-\mathrm{MeOH} ; 1: 9\right.$, v/v), followed by PTLC eluted with (ethyl acetate: $\mathrm{MeOH} ; 2.1: 2.9 ; \mathrm{v} / \mathrm{v}$ ) to give quercetin 3- $O$ - $\alpha$-L-rhamnopyranosyl-( $1 \rightarrow 6)-\beta$-D-glucopyranoside (rutin) (5), while fraction (V) was purified on silica gel sub-column eluted with (EtOAc-MeOH; 17: 3, v/v), followed by PTLC eluted with (ethyl acetate-MeOH; 2.8:2.2, v/v) to give 1,6,8trihydroxy-3-methoxy-9,10-dioxo-9,10-dihydroanthracene (6).

Antimicrobial Activity. The antimicrobial activity was evaluated by filter paper disc method [22]. Briefly, filter paper discs, $5 \mathrm{~mm}$ diameter, were saturated with $200 \mu \mathrm{g}$ of tested extracts (EtOAc and $n$-BuOH). Stock cultures of the test organisms were obtained from the Microbiological Laboratory, Faculty of Medicine, Mansoura University. The test microbes used were Gram-positive bacteria (Staphylococcus aureus, Streptococcus pyogenes, Bacillus subtilis, and Staphylococcus epidermis), Gram-negative bacteria (Klebsiella pneumoniae, Escherichia coli, Erwinia carotovora, Shigella sp., Erwinia sp., Enterobacter aerogenes, Pseudomonas aeruginosa, and Proteus vulgaris), and yeast (Candida albicans). The bacterial test microbes $\left(10^{6}\right.$ cells $\left./ \mathrm{mL}\right)$ were swapped on plates containing nutrient agar medium (DSMZ1), whereas the fungus test microbe $\left(10^{8} \mathrm{cell} / \mathrm{mL}\right)$ was swapped on plates containing Czapek-Dox medium (DSMZ130). The filter paper discs containing the tested extracts were put on the surfaces of the inoculated plates. The plates were then incubated at $37^{\circ} \mathrm{C}$ and $30{ }^{\circ} \mathrm{C}$, for bacteria and fungus test microbes, respectively. The appearance of clear zones (mm diameter) was detected after $24 \mathrm{~h}$ of incubation. The activity index (\%) is also measured as a correlation of the clear zone of tested extract compared to standard antibiotics (ampicillin, streptomycin, kanamycin, tobramycin, and clotrimazole). The activity index was measured according to the following equation:

\section{$\%$ Activity Index}

$$
=\frac{\text { Zone of inhibition by test compound }(\text { diametre })}{\text { Zone of inhibition by standard }(\text { diametre })} \times 100 \%
$$

Anticancer Activity via Microculture Tetrazolium Assay (MTT). The anticancer activity was done according to Mauceri et al. [23], using four human tumor cell lines, namely, hepatocellular carcinoma (HePG-2), mammary gland breast cancer (MCF-7), human prostate cancer (PC3), and epithelioid carcinoma (Hela). The cell lines were obtained from American Type Culture Collection (ATCC) via Holding company for biological products and vaccines (VACSERA), Cairo, Egypt. 5-Fluorouracil was used as a standard anticancer drug for comparison. Briefly, the different cell lines mentioned above were used to determine the inhibitory effects of extracts and compound 3 on cell growth using the MTT assay. This colorimetric assay is based on the conversion of the yellow tetrazolium bromide (MTT) to a purple formazan derivative by mitochondrial succinate dehydrogenase in viable cells. The cells were cultured in RPMI-1640 medium with $10 \%$ fetal bovine serum. Antibiotics added were 100 units $/ \mathrm{mL}$ penicillin and $100 \mu \mathrm{g} / \mathrm{mL}$ streptomycin at $37{ }^{\circ} \mathrm{C}$ in a $5 \% \mathrm{CO}_{2}$ incubator. The cells were seeds in a 96-well plate at a density of $1.0 \times$ 104 cells/well at $37{ }^{\circ} \mathrm{C}$ for $48 \mathrm{~h}$ under $5 \% \mathrm{CO}_{2}$. After incubation, the cells were treated with different concentration of compounds and incubated for $24 \mathrm{~h}$. After $24 \mathrm{~h}$ of drug treatment, $20 \mu \mathrm{L}$ of MTT solution at $5 \mathrm{mg} / \mathrm{mL}$ was added and incubated for $4 \mathrm{~h}$. Dimethyl sulfoxide (DMSO) in volume of $100 \mu \mathrm{L}$ is added into each well to dissolve the purple formazan formed. The colorimetric assay is measured and recorded at absorbance of $570 \mathrm{~nm}$ using a plate reader (EXL 800 , USA). The relative cell viability in percentage was calculated as (A570 of treated samples/A570 of untreated sample) $\times 100$.

Antioxidant Activity (ABTS assay). The antioxidant activity was evaluated via 2,2-azino-di-[3-ethylbenzo-thiazolinsulfonate] (ABTS) method. Briefly, for each of the investigated sample, $2 \mathrm{~mL}$ of ABTS solution $(60 \mathrm{mM})$ was added to $3 \mathrm{M}$ $\mathrm{MnO}_{2}$ solution $(25 \mathrm{mg} / \mathrm{mL})$, all prepared in phosphate buffer $(\mathrm{pH}$ 7, $0.1 \mathrm{M}$ ). The mixture was shaken, centrifuged, and filtered, and the absorbance $\left(A_{\text {control }}\right)$ of the resulting green-blue solution (ABTS radical solution) was adjusted at ca. 0.5 at $1734 \mathrm{~nm}$. Then, $50 \mu \mathrm{L}$ of $(2 \mathrm{mM})$ solution of the test compound in spectroscopic grade $\mathrm{MeOH}-$ phosphate buffer (1:1) was added. The absorbance $\left(A_{\text {test }}\right)$ was measured after $10 \mathrm{~min}$, and the reduction in color intensity was expressed as $\%$ inhibition. The $\%$ inhibition for each compound is calculated from the following equation:

$$
\% \text { Inhibition }=A_{\text {control }}-A_{\text {test }} / A_{\text {control }} \times 100
$$

Ascorbic acid (vitamin C) was used as standard antioxidant (positive control). Blank sample was run without ABTS and using $\mathrm{MeOH}-$ phosphate buffer (1:1) instead of sample. Negative control sample was run with $\mathrm{MeOH}-$ phosphate buffer $(1: 1)$ instead of tested sample [24].

\section{Results and Discussion}

Phytochemical Investigations. Bio-guided fractionation and chromatographic isolation of the ethyl acetate, $n$-butanol, and methylene chloride extracts of $S$. italica resulted in isolation and identification of six compounds (1-6) (Figure 5). The structure of the isolated compounds was elucidated by conventional chemical and spectroscopic methods and via comparison of their spectral data with the literature; the isolated compounds were identified as physcion (1) [25-27], emodin (2) [26-28] , 2-methoxy-emodin-6$O$ - $\beta$-D-glucopyranoside (3), 1-hydroxy-2-acetyl-3-methyl-6hydroxy-8-methoxynaphthalene (tinnevellin) (4) [29], quercetin 3$O$ - $\alpha$-L-rhamnopyranosyl-( $1 \rightarrow 6)-\beta$-D-glucopyranoside (5) (rutin) 
[30, 31], and 1,6,8-trihydroxy-3-methoxy-9,10-dioxo-9,10dihydroanthracene (6) [32].

Structural Elucidation of the Isolated Compounds (1-6). Compound 1 was obtained as orange needles, m.p. 206-207 ${ }^{\circ} \mathrm{C}$ and $R_{\mathrm{f}} 0.58$ in ( $n$-hexane-benzene-ethyl acetate; $2: 0.4: 2.6$; TLC). ${ }^{1} \mathrm{H}-\mathrm{NMR}$ (400 MHZ, DMSO- $\left.d_{6}\right): 7.70(1 \mathrm{H}, \mathrm{s}, \mathrm{H}-5), 7.40(1 \mathrm{H}, \mathrm{d}$, $J=2.1 \mathrm{~Hz}, \mathrm{H}-4), 7.15(1 \mathrm{H}, \mathrm{s}, \mathrm{H}-7), 6.68(1 \mathrm{H}, \mathrm{d}, J=2.1 \mathrm{~Hz}$, $\mathrm{H}-2), 3.94\left(3 \mathrm{H}, \mathrm{s},-\mathrm{OCH}_{3}\right)$, and $2.41\left(3 \mathrm{H}, \mathrm{s},-\mathrm{CH}_{3}\right)$. Therefore, via comparing the given spectal data of the compound with the literature, compound 1 was identified as physcion [25-27].

Compound 2 was obtained as orange needles, m.p. 255$256{ }^{\circ} \mathrm{C}$ and $R_{\mathrm{f}} 0.53$ in ( $n$-hexane-benzene-ethyl acetate; 2:0.4:2.6; TLC). ${ }^{1} \mathrm{H}-\mathrm{NMR}$ (400 MHZ, DMSO- $\left.d_{6}\right): 7.73(1 \mathrm{H}$, s, H-5), $7.50(1 \mathrm{H}, \mathrm{d}, J=2.0 \mathrm{~Hz}, \mathrm{H}-4), 7.21(1 \mathrm{H}, \mathrm{s}, \mathrm{H}-7)$, $6.62(1 \mathrm{H}, \mathrm{d}, J=2.0 \mathrm{~Hz}, \mathrm{H}-2)$, and $2.50\left(3 \mathrm{H}, \mathrm{s},-\mathrm{CH}_{3}\right)$. Therefore, via comparing the given spectal data of the compound with the literature, compound $\mathbf{2}$ was identified as emodin [26-28].

Compound 3 was obtained as dark yellow powder, m.p. $173-175{ }^{\circ} \mathrm{C}$ and $R_{\mathrm{f}} 0.43$ (EtOAc-MeOH- $\mathrm{H}_{2} \mathrm{O} ; 8.6: 1: 0.4$ ). ${ }^{1} \mathrm{H}-\mathrm{NMR}$ spectrum of compound 3 showed two intense singlet signals at $\delta 12.06$ and $12.15 \mathrm{ppm}$ which indicate the chelated hydroxyl proton resonance attached on C-1 and C-8 of the aromatic ring, respectively. The two meta coupled doublet signals at $\delta 6.93$ and $7.04 \mathrm{ppm}$ correspond to the aromatic proton attached on C-5 and C-7, respectively, and a broad singlet signal at $\delta 7.67 \mathrm{ppm}$ was assigned for aromatic proton attached on C-4. A strong intense signal around $2.5 \mathrm{ppm}$ integrated for three protons of methyl proton attached on C-3 of the aromatic ring. Anomeric proton signal attached to C-6 at $\delta 5.01 \mathrm{ppm}$. Additionally, a signal in the aliphatic region was observed at $\delta 3.2 \mathrm{ppm}$ as a singlet and integrated to three protons of methoxyl group at C-2. The ${ }^{13} \mathrm{C}-\mathrm{NMR}$ spectrum showed one methyl carbon at $\delta 21.65 \mathrm{ppm}$ and three oxygenated carbons at $\delta 161.8$ (C-1), 165.1 (C-6), and 164.9 (C-8) ppm. The ${ }^{13} \mathrm{C}-\mathrm{NMR}$ also shows two carbonyl carbons at $\delta 190.1$ (C-9) and 181.9 (C-10) ppm. One methyl substituted carbon at $\delta 148.7$ (C-3); four quaternary carbons at $\delta 127.6(\mathrm{C}-2)$, 120.9 (C-4), 109.3 (C-5), and 109.3 (C-7) ppm; also four quaternary carbons at $\delta 135.6$ (C-11), 109.4 (C-12), 113.8 (C-13), and $133.3(\mathrm{C}-14) \mathrm{ppm}$. The anomeric proton assigned at $\delta 5.01 \mathrm{ppm}$ (d, $J=5.4 \mathrm{~Hz}$ ) through its one-bond correlation in Heteronuclear Single Quantum Coherence (HSQC) with its own anomeric carbon signal at $\delta 100.5 \mathrm{ppm}$ was an evidence for the presence of a glucoside. The upfield shift of the carbon at $\delta 165.1$ (C-6) indicates the presence of sugar moiety on the benzene ring at this position. The attachment of a glucose moiety to C-6 was assigned on the basis of the three-bond correlation peak between $\mathrm{H}-\mathrm{1}^{\prime}$ at $\delta 5.01 \mathrm{ppm}$ and C-6 at $\delta 165.1 \mathrm{ppm}$ in the Heteronuclear Multiple Bond Correlation (HMBC) spectrum. The glucose moiety was deduced to have the $\beta-{ }^{4} \mathrm{C}_{1}$-pyranose stereo structure based on the $J$ value of the anomeric proton and $\delta$ values of its ${ }^{1} \mathrm{H}$ and ${ }^{13} \mathrm{C}$ resonances (Table 1 and Figures 1-5). Similarly, the connectivity of the methoxyl group to $\mathrm{C}-2$ of the aglycone was proven by the correlation peak of $-\mathrm{OCH}_{3}$ at $\delta 3.2 \mathrm{ppm}$ and $\mathrm{C}-2$ at $\delta 127.6 \mathrm{ppm}$. All other ${ }^{1} \mathrm{H}$ and ${ }^{13} \mathrm{C}$ resonances were also confirmed by the ${ }^{1} \mathrm{H}-{ }^{1} \mathrm{H}-\mathrm{COrrelated} \mathrm{SpectroscopY}\left({ }^{1} \mathrm{H}-{ }^{1} \mathrm{H}-\mathrm{COSY}\right)$, HSQC, and HMBC spectra and by comparison with previously reported data for structurally related compounds [33]. Thus, compound 3 was identified as; 2 -methoxyemodin-6- $O-\beta$-Dglucopyranoside, it was isolated for the first time as a new compound.

Compound 4 was obtained as a pale yellow powder, m.p. 163-165 ${ }^{\circ} \mathrm{C}$ and $R_{\mathrm{f}} 0.53$ (EtOAc-MeOH; 3.1:1.9; TLC). ${ }^{1} \mathrm{H}-\mathrm{NMR}$ spectra of compound 4 revealed the presence of three characteristic signals were assigned to three aromatic protons at $\delta 7.10(1 \mathrm{H}, \mathrm{s}, \mathrm{H}-4), 6.97(1 \mathrm{H}, \mathrm{s}, \mathrm{H}-5)$, and $6.75(1 \mathrm{H}, \mathrm{s}, \mathrm{H}-7)$.
Table 1. ${ }^{1} \mathrm{H}$ - and ${ }^{13} \mathrm{C}$ NMR spectral data $\left(400 / 100 \mathrm{MHz}\right.$, DMSO- $\left.d_{6}\right)$ and HMBC assignments of compound $\mathbf{3}$

\begin{tabular}{lccc}
\hline Position & ${ }^{a} \delta_{H} \mathrm{ppm}$ & $\delta_{C} \mathrm{ppm}$ & $\begin{array}{c}\text { HMBC (H-C) } \\
\text { correlations }\end{array}$ \\
\hline 1 & - & 158 & \\
2 & - & 121.4 & - \\
3 & - & 134.3 & \\
4 & $7.03,1 \mathrm{H}, \mathrm{s}$ & 119.3 & \\
5 & - & 103.3 & $\mathrm{C}-5,12$ \\
6 & $6.92,1 \mathrm{H}, \mathrm{d}, J=1.2 \mathrm{~Hz}$ & 156.9 & \\
7 & $-7,1 \mathrm{H}, \mathrm{d}, J=1.2 \mathrm{~Hz}$ & 98.2 & $\mathrm{C}-7,12$ \\
8 & - & 152.2 & \\
$4 \mathrm{a}$ & - & 136.6 & \\
$8 \mathrm{a}$ & - & 109.0 & \\
9 & 2.50 & 205.0 & \\
$10-\mathrm{CH}_{3}$ & 2.24 & 32.3 & \\
$11-\mathrm{CH}_{3}$ & 4.02 & 19.7 & \\
$12-\mathrm{OCH}_{3}$ & $5.02,1 \mathrm{H}, \mathrm{d}, J=7.2 \mathrm{~Hz}$ & 56.3 & \\
$1^{\prime}$ & - & 100.5 & $\mathrm{C}-6$ \\
$2^{\prime}$ & - & 73.6 & $\mathrm{C}-4^{\prime}$ \\
$3^{\prime}$ & - & 77.2 & $\mathrm{C}-1^{\prime}, 5^{\prime}$ \\
$4^{\prime}$ & - & 69.9 & $\mathrm{C}-2^{\prime}, 6^{\prime}$ \\
$5^{\prime}$ & - & 76.8 & $\mathrm{C}^{\prime} 3^{\prime}$ \\
$6^{\prime}$ & & 60.5 & $\mathrm{C}-4^{\prime}$
\end{tabular}

${ }^{a} \mathrm{H}$ : Chemical shift values ( $\delta$ ppm from SiMe4) followed by multiplicity and then the coupling constants $(J$ in $\mathrm{Hz})$.

Also, the spectrum revealed the presence of three methyl protons at $\delta 2.51\left(3 \mathrm{H}, \mathrm{s}, \mathrm{CH}_{3} \mathrm{CO}\right)$ which were assigned to acetyl moiety, three protons of methyl group at $\delta 2.23\left(3 \mathrm{H}, \mathrm{s}, \mathrm{CH}_{3}\right)$, and three methoxyl protons at $\delta 4.17\left(3 \mathrm{H}, s, \mathrm{OCH}_{3}\right)$. Therefore, via comparing the given spectal data of the compound with the literature, compound 4 was identified as1-hydroxy-2-acetyl-3-methyl-6hydroxy-8-methoxynaphthalene (tinnevellin) [29].

Compound 5 was isolated as a yellow powder, m.p. 210 $212{ }^{\circ} \mathrm{C}$ and $R_{\mathrm{f}} 0.67$ (n-hexane-ethyl acetate; 2.1:2.9; TLC). ${ }^{1} \mathrm{H}-\mathrm{NMR}$ spectrum of compound $\mathbf{5}$ revealed the presence of several signals were resonated at $\delta 7.56\left(1 \mathrm{H}, \mathrm{d}, J=2.0 \mathrm{~Hz}, \mathrm{H}-2^{\prime}\right)$, $7.53\left(1 \mathrm{H}, \mathrm{dd}, J=9.2,2.0 \mathrm{~Hz}, \mathrm{H}-6^{\prime}\right), 6.87(1 \mathrm{H}, \mathrm{d}, J=8.8 \mathrm{~Hz}$, H-5'), $6.36(1 \mathrm{H}, \mathrm{d}, J=2.0 \mathrm{~Hz}, \mathrm{H}-8), 6.19(1 \mathrm{H}, \mathrm{d}, J=2.0 \mathrm{~Hz}$, H-6); sugar: $\delta$ (ppm): $5.34\left(1 \mathrm{H}, \mathrm{d}, J=7.2 \mathrm{~Hz}, \mathrm{H}-1^{\prime \prime}\right), 4.39(1 \mathrm{H}$, d, $\left.J=2.8 \mathrm{~Hz}, \mathrm{H}-1^{\prime \prime \prime}\right), 3.17-3.64$ (9H, m, H-2"- H-6", H-2"'- H-5"') and $1.01\left(3 \mathrm{H}, \mathrm{d}, J=6.4 \mathrm{~Hz}, \mathrm{Rha}-\mathrm{CH}_{3}\right)$. Therefore, according to the abovementioned spectral data, compound $\mathbf{5}$ was identified as quercetin 3 - $O$ - $\alpha$-L-rhamnopyranosyl- $(1 \rightarrow 6)-\beta$-D-glucopyranoside (rutin) [30, 31].

Compound 6 was obtained as reddish fine crystals, $R_{\mathrm{f}} 0.74$ ( $n$-hexane-ethyl acetate; 2.8:2.2; TLC). ${ }^{1} \mathrm{H}-\mathrm{NMR}$ spectra of compound 6 revealed the presence of four characteristic signals assigned to four aromatic protons in anthracene nucleus at $\delta 7.55(1 \mathrm{H}, \mathrm{s}, \mathrm{H}-2), 6.20(1 \mathrm{H}, \mathrm{s}, \mathrm{H}-4), 6.50(1 \mathrm{H}, \mathrm{s}, \mathrm{H}-5)$, and $7.80(1 \mathrm{H}, \mathrm{s}, \mathrm{H}-7)$. A methoxyl group was appeared at $\delta 3.80\left(3 \mathrm{H}, \mathrm{s}, \mathrm{OCH}_{3}\right)$. Therefore, via comparing the given spectal data of the compound with the literature, compound $\mathbf{6}$ was identified as 1,6,8-trihydroxy-3-methoxy-9,10-dioxo-9,10dihydroanthracene [32].

\section{Biological Investigations}

Anticancer Activity. The anticancer activity of compound 3, ethyl acetate, and $n$-butanol extracts was evaluated against four human tumor cell lines, namely, hepatocellular carcinoma (HePG-2), mammary gland breast cancer (MCF-7), human prostate cancer (PC3), and cervical (HeLa). The anticancer activity was expressed by the $\mathrm{IC}_{50}$ values as shown in Table 2; also the relative viability of cells (\%) are showing in Figures $6 \mathrm{a}-\mathrm{c}$. According to the American National Cancer Institute guidelines [33], extracts with $\mathrm{IC}_{50}$ values $<30 \mu \mathrm{g} / \mathrm{mL}$ were considered active. It was found that the $n$-butanol extract was active against HePG-2, HeLa, PC3, and MCF-7 human tumor cell lines with an $\mathrm{IC}_{50}$ of $25.9,22.7,21.9$, and $29.5 \mu \mathrm{g} / \mathrm{mL}$; respectively. Moreover, compound $\mathbf{3}$ showed a moderate activity 


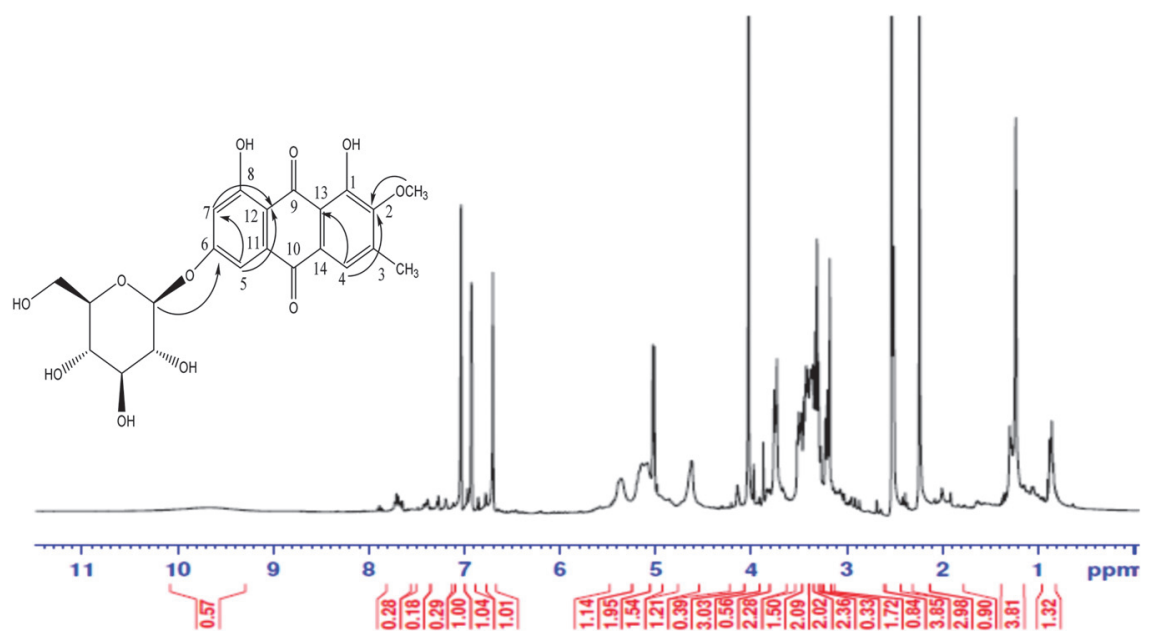

Figure 1. ${ }^{1} \mathrm{H}-\mathrm{NMR}$ spectra of compound 3

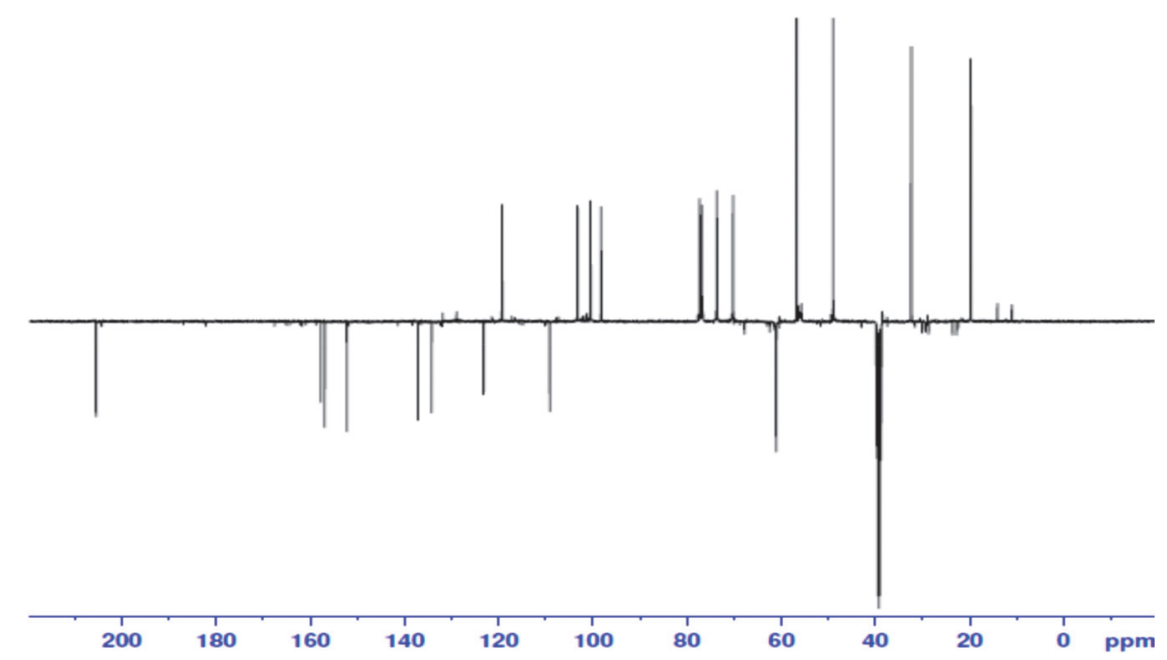

Figure 2. DEPTQ-NMR spectra of compound $\mathbf{3}$

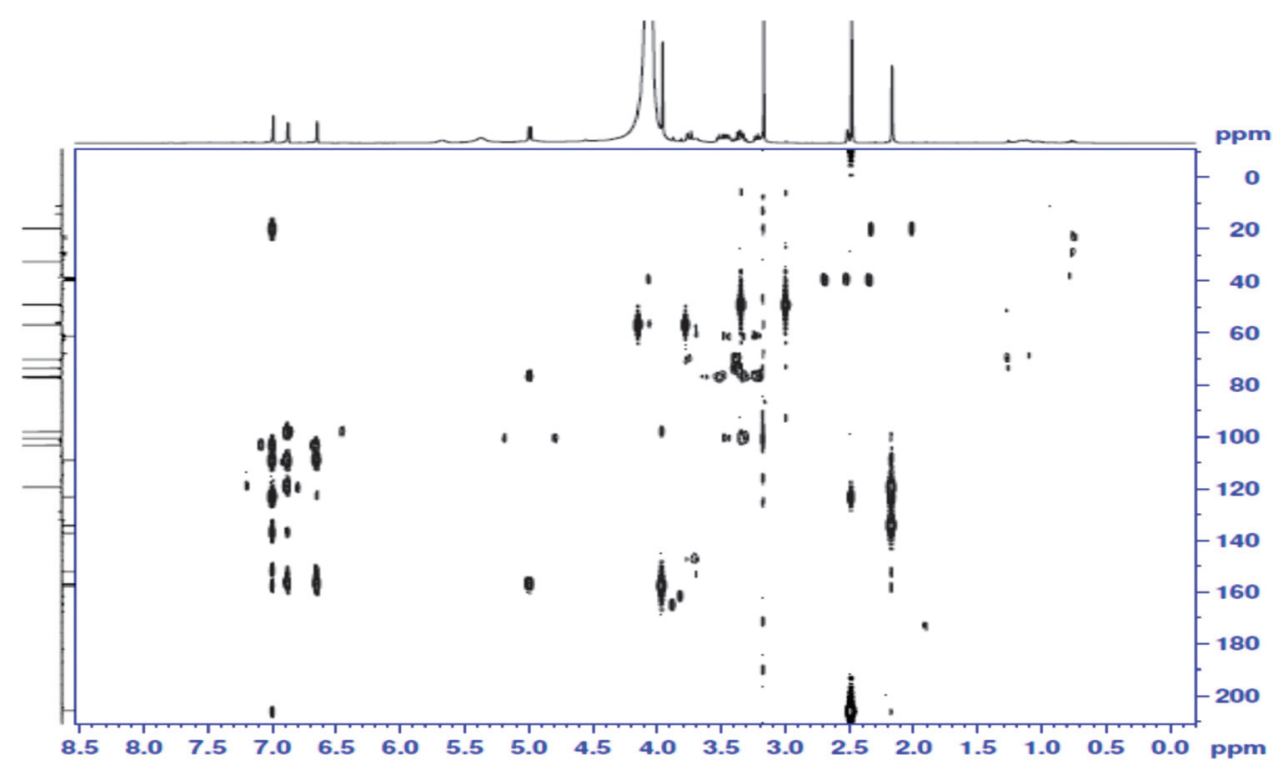

Figure 3. HMBC-NMR spectra of compound 3

only against two tumor cell lines, namely, HePG-2 and MCF-7 with an $\mathrm{IC}_{50}$ of 57.5 and $42.3 \mu \mathrm{g} / \mathrm{mL}$, respectively, compared to 5 -fluorouracil. Previous study revealed that the $n$-hexane extract of $S$. italica showed weak anticancer, while the methylene chloride showed strong anticancer activity against four tested tumor cell lines, namely, HePG-2, HeLa, PC3, and MCF-7
[34]. Many previous reports revealed that the anthraquinonesrich extracts have noticeable in vitro anticancer potentials against different cancer cell lines [35, 36]. Moreover, previous molecular studies showed that the anticancer activity of anthraquinones may return to their unique chemical structure with heavy hydroxylation pattern $[37,38]$. 


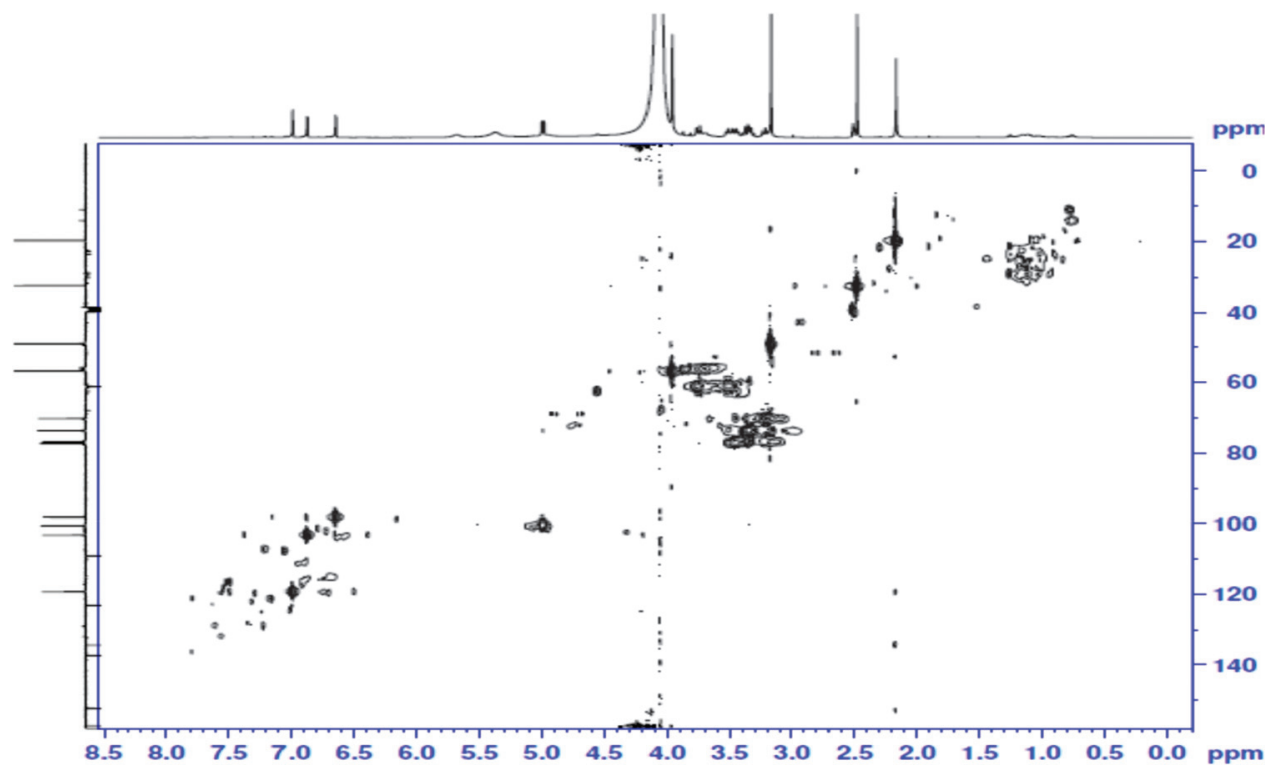

Figure 4. HSQC-NMR spectra of compound 3<smiles>COc1cc(O)c2c(c1)C(=O)c1cc(C)cc(O)c1C2=O</smiles><smiles>Cc1cc(O)c2c(c1)C(=O)c1cc(O)cc(O)c1C2=O</smiles>

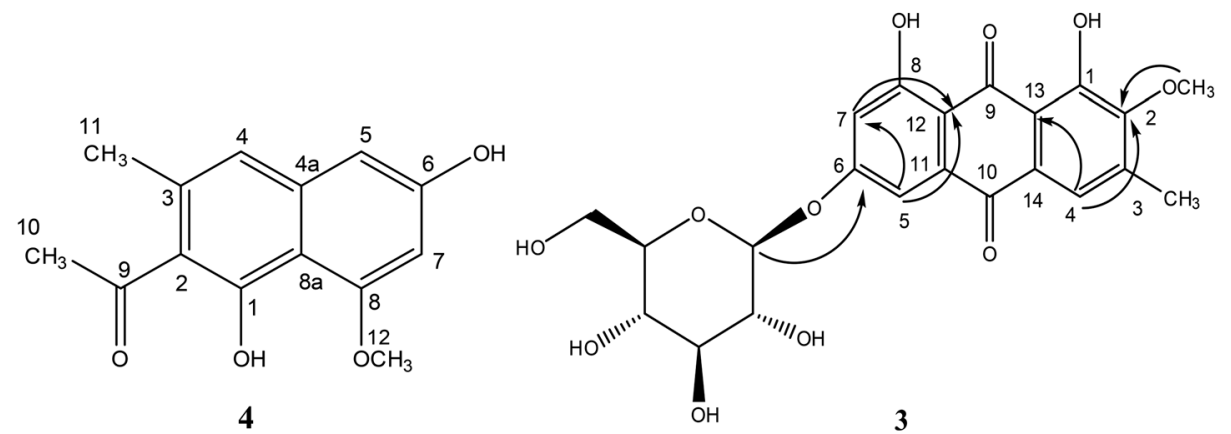

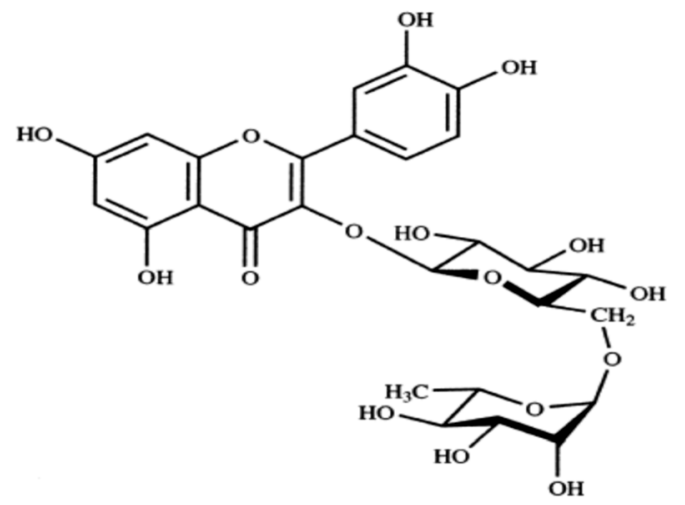<smiles>COc1cc(O)c2c(c1)C(=O)c1cc(O)cc(O)c1C2=O</smiles>

5

Figure 5. Chemcial structures of the isolated compounds (1-6) from aerail part of S. italica.

Antioxidant Activity (ABTS Assay). Free radical scavenging activity of the ethyl acetate and $n$-butanol extracts was evaluated via ABTS assay. The antioxidant activity (\% inhibition) against
ABTS radical was $82.9 \%$ and $85.7 \%$, respectively, for the ethyl acetate and $n$-butanol extracts, compared to ascorbic acid with \% inhibition of $89.2 \%$ (Table 3 and Figure 7). Masoko et al. (2010) 
Table 2. Anticancer activity of ethyl acetate and $n$-butanol extracts as well as compound $\mathbf{3}$ against human tumor cells compared to 5-fluorouracil as standard

\begin{tabular}{|c|c|c|c|c|}
\hline \multirow[t]{2}{*}{ Samples } & \multicolumn{4}{|c|}{ In vitro anticancer $\mathrm{IC}_{50}(\mu \mathrm{g} / \mathrm{mL})^{a}$} \\
\hline & Hep G2 & Hela & PC3 & MCF-7 \\
\hline$\overline{5-\mathrm{FU}^{b}}$ & $7.9 \pm 0.28$ & $4.8 \pm 0.21$ & $8.3 \pm 0.35$ & $5.4 \pm 0.20$ \\
\hline Ethyl acetate & $46.1=$ & $59.1 \pm 3.57$ & $28.7 \pm$ & 53.9 \\
\hline$n$-Butanol & $25.9=$ & $22.7 \pm 1.62$ & $21.9 \pm 1.76$ & 29.5 \\
\hline Compound 3 & $57.5 \pm 4.26$ & - & - & $42.3 \pm 3.25$ \\
\hline \multicolumn{5}{|c|}{$\begin{array}{l}{ }^{a} \mathrm{IC}_{50}(\mu \mathrm{g} / \mathrm{mL}): 1-10 \text { (very strong), } 11-20 \text { (strong), } 21-50 \text { (moderate), } \\
51-100 \text { (weak), and above } 100 \text { (non-cytotoxic). } \\
{ }^{b} 5-\mathrm{FU}=5 \text {-fluorouracil. }\end{array}$} \\
\hline
\end{tabular}

have been reported on the antioxidant activity of the acetone extract of the roots of $S$. italica, and such activity was attributed to the presence of bio-active chemical ingredients like glycosides, flavonoids, and alkaloids [12]. Anthraquinone compounds are known by their antioxidant potentials [39-42]. The anthraquinone nucleus showed optimum structural criteria required for the good antioxidant activity including heavy hydroxylation pattern and electron delocalization through conjugated system; accordingly, anthraquinones can act as strong electron and hydrogen donors $[43,44]$. Therefore, in our current study, the high antiradical activity may be owing to these anthraquinones-rich extracts (EtOAc and $n-\mathrm{BuOH})$.

Antimicrobial Activity. The antimicrobial activity of the ethyl acetate and $n$-butanol extracts was examined via disc agar technique against twelve pathogenic microbial strains. The
Table 3. Antioxidant activity of ethyl acetate and $n$-butanol extracts of Senna italica using ABTS assay

\begin{tabular}{lcc}
\hline Sample & Absorbance of samples & $\%$ Inhibition \\
\hline Ethyl acetate & 0.087 & $82.9 \%$ \\
$n$-Butanol & 0.073 & $85.7 \%$ \\
Ascorbic acid & 0.055 & $89.2 \%$ \\
Control of ABTS & 0.510 & $0 \%$ \\
\hline
\end{tabular}

results in Table 4 revealed that ethyl acetate extract showed a moderate to strong antimicrobial activity against seven tested organisms with inhibition zones ranged from 6 to $16 \mathrm{~mm}$. On the other hand, $n$-butanol extract showed a remarkable activity against eleven species in comparing to standard antibiotics, i.e., Shigella spp. (7.8 mm/streptomycin, $14 \mathrm{~mm})$, Erwinia spp. (10 mm/streptomycin, $35 \mathrm{~mm})$, E. coli (19 mm/ampicillin, $24 \mathrm{~mm})$, E. aerogenes $(12.4 \mathrm{~mm} /$ kanamycin, $20 \mathrm{~mm}), \quad P$. aeruginosa (6.1 mm/tobramycin, $15 \mathrm{~mm}), P$. vulgaris $(7 \mathrm{~mm} /$ ampicillin, $18 \mathrm{~mm}), S$. epidermis (14 mm/ampicillin, $24 \mathrm{~mm}), S$. pyogenes (10 mm/ampicillin, $20 \mathrm{~mm}), S$. aureus (11 mm/ampicillin, $24 \mathrm{~mm})$, B. subtilis $(9.3 \mathrm{~mm} / \mathrm{kanamycin}, 20 \mathrm{~mm})$, and C. albicans (12 mm/clotrimazole, $20 \mathrm{~mm})$. The antimicrobial activity of the different parts of $S$. italica was previously investigated, and the obtained results to some extent were matched with our finding $[34,45]$. Regarding the abovementioned results of the anthraquinone-rich extracts, these results may be good indicators for the responsibility of the identified anthraquinone metabolites for this activity shown by these extracts (EtOAc and $n$-BuOH). From the
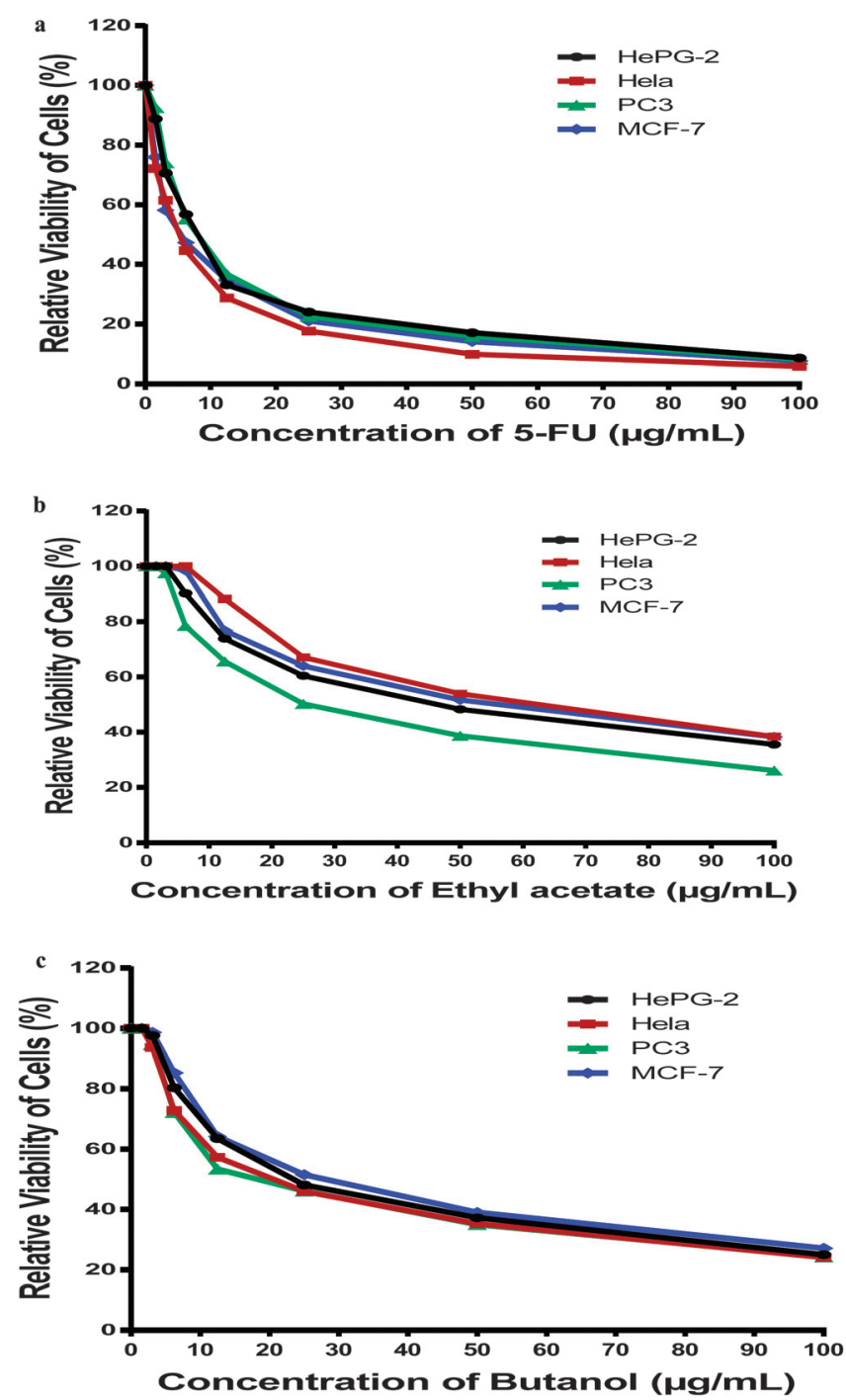

Figure 6. (a) Relative viability of cells (\%) against different concentrations 5-fluorouracil as standard; (b) relative viability of cells (\%) against different concentrations of ethyl acetate; (c) relative viability of cells (\%) against different concentrations of $n$-butanol 


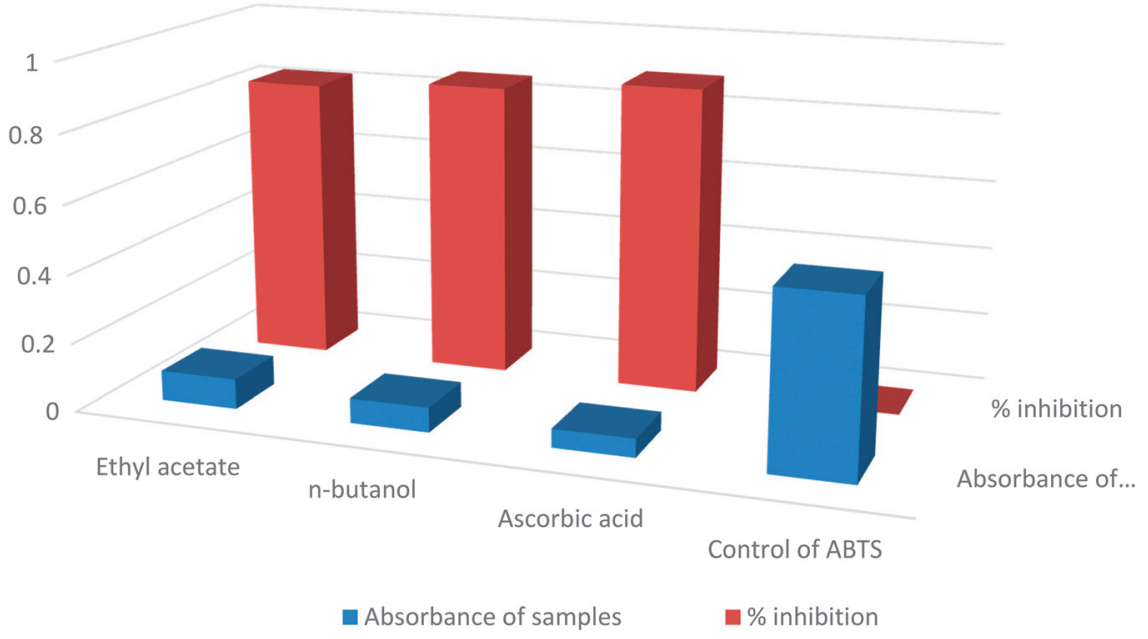

Figure 7. Antioxidant activities of ethyl acetate and $n$-butanol extracts of $S$. italica using ABTS assay

Table 4. The inhibition zone $(\mathrm{mm})$ and activity index $\%$ of ethyl acetate and $n$-butanol extracts of $S$. italica compared to standard antibiotics

\begin{tabular}{|c|c|c|c|c|c|}
\hline \multirow[t]{2}{*}{ Microorganism } & \multirow{2}{*}{$\begin{array}{c}\text { Standard antibiotic/Inhibition } \\
\text { zone }(\mathrm{mm})\end{array}$} & \multicolumn{2}{|c|}{ Ethyl acetate } & \multicolumn{2}{|c|}{$n$-Butanol } \\
\hline & & Inhibition zone $(\mathrm{mm})^{a}$ & Activity index $\%$ & Inhibition zone $(\mathrm{mm})$ & Activity index $\%$ \\
\hline Klebsiella pneumoniae & Ampicillin/25 & 0 & 0 & 0 & 0 \\
\hline Shigella spp. & Streptomycin/14 & 8.6 & 61.4 & 7.8 & 55.7 \\
\hline Erwinia spp. & Streptomycin/35 & 8 & 22.8 & 10 & 28.5 \\
\hline Escherichia coli & Ampicillin/24 & 16 & 66.6 & 19 & 79.1 \\
\hline Enterobacter aerogenes & Kanamycin/20 & 9 & 45.0 & 12.4 & 62.0 \\
\hline Pseudomonas aeruginosa & Tobramycin/15 & 0 & 0 & 6.1 & 40.6 \\
\hline Proteus vulgaris & Ampicillin/18 & 0 & 0 & 7 & 38.8 \\
\hline Staphylococcus epidermis & Ampicillin/24 & 0 & 0 & 14 & 58.3 \\
\hline Streptococcus pyogenes & Ampicillin/20 & 0 & 0 & 10 & 50.0 \\
\hline Staphylococcus aureus & Ampicillin/24 & 6 & 25.0 & 11 & 45.8 \\
\hline Bacillus subtilis & Kanamycin/20 & 14 & 70.0 & 9.3 & 46.5 \\
\hline Candida albicans & Clotrimazole/20 & 6 & 30.0 & 12 & 60.0 \\
\hline${ }^{a}$ Inhibition zones in $\mathrm{mm}$. & & & & & \\
\hline
\end{tabular}

structure activity relationship point of view, anthraquinones have the ability to act as antimicrobial agents via different modes of actions, in which the interaction with cell wall/cell membrane, leading to increase the permeability of the cell envelope, the leakage of cytoplasm, and the deconstruction of cell [46]. In addition, many authors have been reported on the antimicrobial activities of anthraquinones [47, 48]. de Barros et al. (2011) reported on the antifungal activity of emodin, physcion from Coccoloba mollis [49]. Also, Basu et al (2005) reported on the antibacterial activity of emodin and physcion against three Bacillus species [50].

\section{Conclusion}

In this work, six phenolic compounds were isolated and identified in the ethyl acetate and $n$-butanol extracts of $S$. italica using chromatographic and spectroscopic techniques. The two solvent extracts showed noticeable antimicrobial, anticancer, and antioxidant activities. Moreover, the $n$-butanol extract showed strong antimicrobial activity than the ethyl actate. Compound 3 was isolated for the first time from $S$. italica growing in Egypt; the aerial parts of $S$. italica may be good natural sources of antimicrobial, antioxidant, and anticancer agents.

\section{Conflict of Interest}

The authors declare that there are no known conflicts of interest associated with this work.

\section{References}

1. Rahman, A. H. M.; Parvin, M. I. A. Plant 2015, 3, 20.

2. Irwin, H. S.; Barneby, R. C. 1982, 35, 1-918.

3. Randell, B. R.; Barlow, B. A. Senna Flora of Australia, 1998, 12, 89-138.
4. Yagi, S.; El-Tigani, S.; Ali, M.; Elkhidir, I.; Mohammed, A. M. A. Int. Lett. Chem. Phys. Astron. 2013, 9, 146.

5. Ingkaninan, K.; Ijzerman, A.; Verpoorte, R. J. Nat. Prod. 2000, 63, 315.

6. Branco, A.; Pinto, A. C.; Schripsema, J.; Braz-Filho, R. An. Acad. Braz. Sci. 2011, 83, 1159 .

7. Bukar, A.; Mukhtar, M. D.; Hassan, A. S. Bayero J. Pure Appl. Sci. 2009, $2,139$.

8. Susunaga-Notario, A. C.; Pérez-Gutiérrez, S.; Zavala-Sánchez, M. A.; Almanza-Pérez, J. C.; Gutiérrez-Carrillo, A.; Arrieta-Báez, D.; López-López, A. L.; Román-Ramos, R.; Flores-Sáenz, J. L.; Alarcón-Aguilar, F. J. Molecules 2014, 19 , 10261.

9. Jimenez-Coello, M.; Guzmán, E. S.; Pérez, M. S.; Polanco, G.; Acosta, K. Afr. J. Tradit. Complement. Altern. Med. 2011, 8, 164.

10. Guzmán, E. S.; Pérez, C.; Zavala, M. A.; Pérez, M. S. Phytomedicine 2008, 15,892 .

11. Mokgotho, M. P.; Gololo, S. S.; Masoko, P.; Mdee, L. K.; Mbazima, V.; Shai, L. J. Evid-Based Compl. Alt. Med. 2013, 1-6.

12. Masoko, P. A.; Gololo, S. S.; Mokgotho, M. P.; Eloff, J. N.; Howard, R. I.; Mampuru, L. J. Afr. J. Tradit. Complement. Altern. Med. 2010, 7, 138.

13. Mohanlall, V.; Odhav, B. J. Med. Plant Res. 2013, 7, 877.

14. Kanokmedhakul, K.; Kanokmedhakul, S.; Phatchana, R. J. Ethnopharmacol. 2005, 100, 284.

15. Manojlovic, N. T.; Solujic, S.; Sukdolak, S.; Krstic, L. J. J. Serb. Chem. Soc. $2000,65,555$.

16. Rossi, S.; Tabolacci, C.; Lentini, A.; Provenzano, B.; Carlomosti, F.; Frezzotti, S.; Beninat, S. Anticancer Res. 2010, 30, 445

17. Lee, H. Z.; Hsu, S. L.; Liu, M. C.; Wu, C. H. Eur. J. Pharmacol. 2001, $431,287$.

18. Mohammed, M. D.; El-Souda, S. S.; El-Hallouty, S. M.; Kobayashi, N. Herba Polonica. 2013, 59, 33.

19. Kuo, P. L.; Lin, T. C.; Lin, C. C. Life Sci. 2002, 71, 1879.

20. Jasril, A.; Lajis, N. H.; Mooi, L. Y.; Abdullah, M. A.; Sukari, M. A.; Ali, A. M. As Pac. J. Mol. Biol. Biotechnol. 2003, 11, 3.

21. Djemgou, P. C.; Hussien, T. A.; Hegazy, M. F.; Ngandeu, F.; Neguim, G.; Tane, P.; Mohamed, A. H. Pharmacognosy Res. 2010, 2, 229.

22. Murray, P. R.; Baron, E. J.; Pfaller, M. A.; Tenover, F. C.; Yolke, R. H. Manual of Clinical Microbiology 6th Ed. ASM, Washington, 1995.

23. Mauceri, H. J.; Hanna, N. N.; Beckett, M. A.; Gorski, D. H.; Staba, M. J.; Stellato, K. A.; Bigelow, K.; Heimann, R.; Gately, S.; Dhanabal, M.; Soff, G. A.; Sukhatme, V. P.; Kufe, D. W.; Weichselbaum, R. R. Nature 1998, 394, 287.

24. El-Gazzar, A. B.; Youssef, M. M.; Youssef, A. M. S.; Abu-Hashem, A. A.; Badria, F. A. Eur. J. Med. Chem. 2009, 44, 609.

25. Li, J. L.; Wang, A. Q.; Li, J. S.; He, W. Y.; Kong, M. Chin. Tradit. Herb. Drugs 2000, 31, 321. 
26. Chu, X.; Sun, A.; Liu, R. J. Chromatogr. A 2005, 1097, 33.

27. Guo, S.; Feng, B.; Zhu, R.; Ma, J.; Wang, W. Molecules 2011, 16, 1201.

28. Yang, X. W.; Gu, Z. M.; Ma, C. M.; Hattori, M.; Namba, T. Chin. Tradit Herb. Drugs 1998, 29, 5-10 11.

29. LemIi, J.; Toppet, S.; Cuveele, J.; Janssen, G. Planta Med. 1981, 43,

30. El-Sayed, M. M.; Mahmoud, M. A.; El-Nahas, H. A.; El-Toumy, S. A. El-Wakil, E. A.; Ghareeb, M. A. Pharmacologyonline 2010, 3, 317.

31. Ghareeb, M. A.; Shoeb, H. A.; Madkour, H. M. F.; Refahy, L. A.; Mohamed, M. A.; Saad, A. M. Global J. Pharmacol. 2014, 8, 87.

32. Ghoneim, M. M.; Elokely, K. M.; El-Hela, A. A.; Mohammad, A. I.; Jacob,

M.; Cutler, S. J.; Doerksen, R. J.; Ross, S. A. Med. Chem. Res. 2014, 23, 3510.

33. Suffness, M.; Pezzuto, J. M. Assays related to cancer drug discovery. In Methods in Plant Biochemistry: Assays for Bioactivity Edited by Hostettmann, K. London: Academic Press, 1990, 6, pp. 71-133.

34. Madkour, H. M. F.; Ghareeb, M. A.; Abdel-Aziz, M. S.; Khalaf, O. M.; Saad, A. M.; El-Ziaty, A. K.; Abdel-Mogib, M. J. Appl. Pharm. Sci. 2017, 7 , 023.

35. Aviello, G.; Rowland, I.; Gill, C. I.; Acquaviva, A. M.; Capasso, F.; McCann, M.; Capasso, R.; Izzo, A. A.; Borrelli, F. J. Cell. Mol. Med. 2010, 14, 2006.

36. Huang, Q.; Lu, G.; Shen, H. C. M.; Chung, M. C. M.; Ong, C. N. Med. Res. Rev. 2007, 27, 609.

37. Driscoll, J. S.; Hazard, G. F.; Wood, J. H. B.; Goldin, J. A. Cancer Chemother. Rep. 1974, 2, 1.
38. Srinivas, G.; Babykutty, S.; Sathiadevan, P. P.; Srinivas, P. Med. Res. Rev. 2007, 27, 591.

39. Jasril, Lajis, N. H.; Mooi, L. Y.; Abdullah, M. A.; Sukari, M. A.; Ali, A. M. Asia. Pac. J. Mol. Biol. Biotechnol. 2003, 11, 3

40. Zhang, X.; Thuong, P. T.; Jin, W. Y.; Su, N. D.; Sok, D. E.; Bae, K.; Kang, S. S. Arch. Pharm. Res. 2005, 28, 22.

41. Lin, H.; Zhang, Y.-W; Zheng, L--H.; Meng, X-Y; Bao, Y.-L.; Wu, Y; Yu, C.-L.; Huang, Y.-X.; Li, Y.-X. Helv. Chim. Acta. 2011, 94, 1488.

42. Tripathi, B.; Bhatia, R.; Pandey, A.; Gaur, J.; Chawala, G.; Walia, S.; Choi, E. H.; Attri, P. J. Chem. 2014, 1.

43. Rice-Evans, C. A.; Miller, N. J.; Paganga, G. Free Radic Biol. Med. 1996, 20, 933.

44. Marković, Z.; Jeremić, S.; Marković, J. M.; Pirković, M. S.; Amić, D. Comput. Theor. Chem. 2016, 1077, 25.

45. Tshikalange, T. E.; Meyer, J. M.; Husein, A. A. J. Ethnopharmacol. 2005, 96, 515 .

46. Wei, Y.; Liu, Q.; Yu, J.; Feng, Q.; Zhao, L.; Song, H.; Wang, W. Nat. Prod. Res. 2014, 1.

47. Agarwal, S. K.; Singh, S. S.; Verma, S.; Kumar, S. J. Ethnopharmacol. 2000, 72,43 .

48. Izhaki, I. New Phytol. 2002, 155, 205.

49. de Barros, I. B.; Daniel, J. F. S.; Pinto, J. P.; Rezende, M. I.; Filho, R. B.; Ferreira, D. T. Braz. Arch. Biol. Technol. 2011, 54, 535.

50. Basu, S.; Ghosh, A.; Banasri, H. Phytother. Res. 2005, 19, 888. 